\title{
Uptake of exogenous and endogenous eicosapentaenoic acid by cultured human mononuclear cells
}

\author{
BY M. J. GIBNEY AND AEDEEN CONNOLLY \\ Division of Nutritional Sciences, Department of Clinical Medicine, Trinity College \\ Medical School, St. James's Hospital, Dublin 8, Irish Republic
}

(Received 15 June 1987 - Accepted 26 January 1988)

\begin{abstract}
1. Peripheral blood mononuclear cells from eight healthy volunteers were cultured, with or without concanavalin A (Con A), in a medium containing (ml/l) 100 normal autologous serum, 100 experimental autologous serum or 100 heterologous (fetal calf) serum.

2. The control and experimental autologous sera were obtained from the volunteers, before and after $15 \mathrm{~d}$ supplementation with $15 \mathrm{~g}$ fish oil (MaxEPA)/d to provide $1.5 \mathrm{~g}$ eicosapentaenoic acid (EPA; 20:5n-3)/d. The sera were frozen at $-20^{\circ}$. The level of EPA increased from trace quantities in the control autologous serum to $14.3 \% \mathrm{w} / \mathrm{w}$ free fatty acids and between 6.9 and $8.1 \% \mathrm{w} / \mathrm{w}$ lipoprotein phospholipids in the experimental autologous serum. The heterologous fetal calf serum was enriched with EPA, complexed with bovine serum albumin, to provide a final concentration of $15 \mu \mathrm{g} / \mathrm{ml}$. All culture medium contained $10 \mathrm{ml}$ fresh autologous serum $/ 1$ and cells were obtained from the volunteers for the culture studies about $60 \mathrm{~d}$ after the end of EPA supplementation.

3. Portions of cells were removed from culture at 36,48 and $72 \mathrm{~h}$ for phospholipid fatty acid analysis.

4. The level of EPA in phospholipids of cells cultured with exogenous EPA in fetal calf serum was increased significantly $(P<0.05)$ at all sampling times, both with and without Con A. By $48 \mathrm{~h}$ the levels had peaked at 15.8 (SE 2.7) and 18.4 (SE 4.5$) \% \mathrm{w} / \mathrm{w}$ respectively.

5. Resting cells, i.e. with no Con A present, failed to accumulate EPA when cultured in the experimental autologous serum containing $8.6 \% \mathrm{w} / \mathrm{w}$ total lipids as endogenous EPA. When cells were stimulated to divide by the mitogen Con A, there was a gradual increase in phospholipid EPA levels of mononuclear cells cultured with experimental autologous serum containing endogenous EPA. The maximum level obtained was at $72 \mathrm{~h}(7 \cdot 2$ (SE $2 \cdot 7)$ ).

6. In a separate experiment, the effect of Con $A$ at increasing doses $(0,1,5,10$ and $20 \mu \mathrm{g}$, final concentration) on lymphocyte blastogenesis was determined by estimating the incorporation of ${ }^{3}[\mathrm{H}]$ thymidine. No significant effects due to serum in the culture medium were observed.
\end{abstract}

In recent years there has been a growing interest in the role of $n-3$ polyunsaturated fatty acids in the regulation of such eicosanoid-dependent processes as haemostasis (Hornstra, 1985 ) and inflammation (Salmon \& Terano, 1985). The main fatty acid of interest has been eicosapentaenoic acid (EPA; 20:5n-3) which can reduce eicosanoid synthesis by displacing membrane phospholipid arachidonic acid (20:4n-6), the physiological substrate for eicosanoid synthesis, by providing a poor substrate (EPA) for the enzymes of eicosanoid synthesis and by yielding inactive or poorly active eicosanoids (Sanders, 1985). In studying the effect of EPA on eicosanoid-dependent processes, a number of experimental approaches are possible. The use of experimental animals offers the advantage over the use of human volunteers in the accessibility of tissues, in the range of possible procedures and in the size and duration of the dietary supplement of EPA. However, extrapolation from animal studies to man requires caution. Most animal studies involve the use of weanling animals over periods ranging from 2 to 33 weeks (Herold \& Kinsella, 1986). Under such circumstances, extensive changes in tissue lipid composition can be achieved because of the rapid growth during the post-weaning period. Such an increase in tissue weight does not occur in adult man and thus extrapolation from growing animals to adult man must be viewed cautiously, particularly for those tissues with a long half-life, e.g. lymphocytes.

Because of the difficulties in human feeding studies, particularly in the accessibility to tissues other than plasma constituents, in vitro studies of the effects of EPA on cell function 
have been used, e.g. cultured human vascular endothelial cells (Spector et al. 1983). In such studies exogenous EPA is added to the culture medium, usually as an EPA-bovine serum albumin (BSA) complex. The use of this technique has been criticized for two reasons. First, the possibility of a direct cytotoxic effect of the fatty acid has been suggested (Gurr, 1983). Second, whilst phospholipid uptake of exogenously added fatty acid is rapid, the uptake occurs into all phospholipid classes (von Schacky \& Weber, 1985) which is in contrast to the pattern observed in human feeding studies where EPA tends to accumulate in the phosphatidyl ethanolamine and phosphatidyl choline fractions, with little uptake into phosphatidyl inositol (Sanders, 1985).

In vivo, EPA will exist in two pools of plasma lipids, the free fatty acid pool and the lipoprotein pool (phospholipid and triglyceride) and it is from either of these pools that EPA will enter tissue cells. The incorporation of plasma lipids into cell lipids can occur either during the life of the cell or during cell maturation. The findings of von Schacky et al. (1985) suggest that the latter may be of most physiological significance. Accordingly, the present study compared the uptake of EPA into cultured human mononuclear cells (peripheral blood mononuclear cells; PBMC) using the conventional in vitro source of exogenous EPA complexed with BSA, and using an autologous serum obtained during a period of fish-oil supplementation and hence enriched in endogenous EPA.

\section{METHODS}

\section{Serum preparation}

Eight healthy volunteers each donated $80 \mathrm{ml}$ fasting blood from which portions of serum were prepared and frozen. This serum was designated as normal autologous serum (NAS). Each volunteer then consumed $15 \mathrm{~g} / \mathrm{d}$ of a fish oil, MaxEPA (British Cod Liver Oils Ltd), for $15 \mathrm{~d}$ which provided an intake of $1.5 \mathrm{~g} \mathrm{EPA} / \mathrm{d}$. On the 15 th day the volunteers again donated $80 \mathrm{ml}$ fasting blood from which portions of serum were prepared and frozen. This serum was designated as experimental autologous serum (EAS). EPA was complexed with BSA according to Magrum \& Johnston (1985) and diluted in Roswell Park Memorial Institute (RPMI) medium containing fetal calf serum $(100 \mathrm{ml} / \mathrm{l})$ to provide a final EPA concentration of $15 \mu \mathrm{g} / \mathrm{ml}$.

\section{Isolation of PBMC}

PBMC were isolated from $50-70 \mathrm{ml}$ heparinized blood, donated by the eight participating volunteers $60 \mathrm{~d}$ after the cessation of EPA supplements. The blood was diluted with Hanksbuffered salt solution (HBSS) and centrifuged at $300 \mathrm{~g}$ for $25 \mathrm{~min}$ at $4^{\circ}$ through a ficollpaque sedimentation gradient. The cells at the interface were collected using a sterile pipette and washed twice for $10 \mathrm{~min}$ at $400 \mathrm{~g}$ in HBSS at $4^{\circ}$. The viability and yield of cells were determined using a solution $(1 \mathrm{~g} / \mathrm{l})$ of ethidium bromide and acridine orange, and both were found to be more than $95 \%$.

\section{Cell cultures}

Expt 1 . The cells were incubated in RPMI $\left(10^{6} / \mathrm{ml}\right)$ containing $100 \mathrm{ml}$ NAS, EAS or fetal calf serum $/ 1$ containing EPA-BSA at a final concentration of $15 \mu \mathrm{g} \mathrm{EPA} / \mathrm{ml}$ culture medium. The cells were cultured in $5-6 \mathrm{ml}$ batches with or without concanavalin A (Con A; $5 \mu \mathrm{g} / \mathrm{ml}$, final concentration). The cultures containing autologous serum were supplemented to a level of $10 \mathrm{ml} / 1$ with fresh autologous serum collected at the point of PBMC isolation. (This was done in case the transfer of lipid to cultured PBMC was dependent on a serum protein which might have become damaged on freezing the portions of NAS and EAS.) Portions were removed at 24, 48 and $72 \mathrm{~h}$ for PBMC phospholipid fatty 
acid analysis and the viability of the cells was checked on each occasion. All culture systems were carried out with gentamycin $(50 \mu \mathrm{g} / \mathrm{ml})$ at $37^{\circ}$ with oxygen - carbon dioxide $(95: 5, \mathrm{v} /$ v) in a humidified chamber.

Expt 2. In this experiment the cells were cultured in portions of $200 \mu \mathrm{l}$ RPMI containing $100 \mathrm{ml}$ NAS, EAS or FCS/l containing EPA-BSA (15 $\mu \mathrm{g} \mathrm{EPA} / \mathrm{ml}$, final concentration) in microtitre plates at a concentration of $10^{6} \mathrm{PBMC} / \mathrm{ml}$. An additional treatment was used in this experiment to control for the effects of BSA, i.e. $100 \mathrm{ml} \mathrm{FCS} / \mathrm{l}$ containing no EPA but a final concentration of BSA equivalent to that used in the EPA-BSA culture treatment. Again the cultures containing NAS and EAS were supplemented as described for Expt 1 with $10 \mathrm{ml}$ fresh autologous serum/l collected at the time of PBMC isolation. The wells, in triplicate, received $20 \mu \mathrm{l}$ supplements of HBSS containing $0,20,50,100$ or $200 \mu \mathrm{g}$ Con A/ $\mathrm{ml}$, to provide final concentrations of $0,2,5,10$ or $20 \mu \mathrm{g}$ Con A $/ \mathrm{ml}$ respectively. At $48 \mathrm{~h}$, $10 \mu$ l HBSS containing $0.3 \mu \mathrm{Ci}\left[{ }^{3} \mathrm{H}\right]$ thymidine $(2 \mu \mathrm{Ci} / \mathrm{mol})$ was added to each portion. At $72 \mathrm{~h}$ the cells were washed and harvested (Multiwash, Dynatech). Filters containing the cells were dried at $45^{\circ}$ for 10 min and placed in vials containing $1 \mathrm{ml}$ scintillation fluid and counted for $10 \mathrm{~min}$ to determine uptake of $\left[{ }^{3} \mathrm{H}\right]$ thymidine as counts $/ \mathrm{min}$. All culture systems were carried out with gentamycin $(50 \mu \mathrm{g} / \mathrm{ml})$ at $37^{\circ}$ with $\mathrm{O}_{2}-\mathrm{CO}_{2}(95: 5, \mathrm{v} / \mathrm{v})$ in a humidified chamber.

\section{Lipid analysis}

Serum total lipids were extracted with chloroform and lipids from washed PBMC were extracted twice with chloroform-methanol $(2: 1, \mathrm{v} / \mathrm{v})$ and the pooled extracts were washed with $0 \cdot 1 \mathrm{M}$-potassium chloride. PBMC phospholipids were isolated by thin-layer chromatography on silica gel 60 (Merck), and plates run in light petroleum (b.p. $40-60^{\circ}$ )-diethyl ether-formic acid $(80: 20: 1$, by vol.). The phospholipids at the origin were located using a spray of 1,6-diphenyl-1,3,5-hexatriene which was subsequently removed with light petroleum (b.p. $40-60^{\circ}$ ). The phospholipids were extracted three times from silica gel scrapings with chloroform-methanol $(2: 1, \mathrm{v} / \mathrm{v})$. The serum total lipids and PBMC phospholipid fatty acids were transmethylated using sodium methoxide and quantified using gas-liquid chromatography on a Pye Unicam Chromatograph: $1.5 \mathrm{~m} \times 4 \mathrm{~mm}$ glass column packed with $10 \%$ silar $10 \mathrm{C}$ on 120 chromasorb WHP with a temperature programme of $150-250^{\circ}$ at $4^{\circ} / \mathrm{min}$. Nitrogen was used as the carrier gas $(48 \mathrm{ml} / \mathrm{min})$ and the flame achieved with hydrogen and $\mathrm{O}_{2}$ at $1 \mathrm{~kg} / \mathrm{ml}$. Both the injection and detector functioned at $200^{\circ}$. Serum lipoproteins were isolated on a Beckman L550 ultracentrifuge (SW41 rotor) on a sucrose-potassium bromide density gradient at $40000 \mathrm{rev} / \mathrm{min}$ for 22 $\mathrm{h}$ at $20^{\circ}$ (Demacker et al. 1983). The tubes were sliced and the lipid analysis of the lipoprotein fractions was similar to that for PBMC.

\section{Statistical analysis}

The results were analysed by analysis of variance and mean values compared using Duncan's multiple range test.

\section{RESULTS}

Following $15 \mathrm{~d}$ supplementation with $1.5 \mathrm{~g}$ EPA/d there was a significant decrease $(P<$ $0.05)$ in the level of 16:0 and significant increases $(P<0.01)$ in the levels of $20: 5 n-3$ and $22: 6 n-3$ in serum total lipids. The increased levels of $20: 5 n-3$ were equally distributed in the phospholipids of each of the lipoprotein fractions; high levels of EPA were also found in the free fatty acid fraction (Table 1). The levels of EPA $(20: 5 n-3)$ increased substantially $(P<0.05)$ in cultures containing the EPA-BSA complex, irrespective of whether the cells 


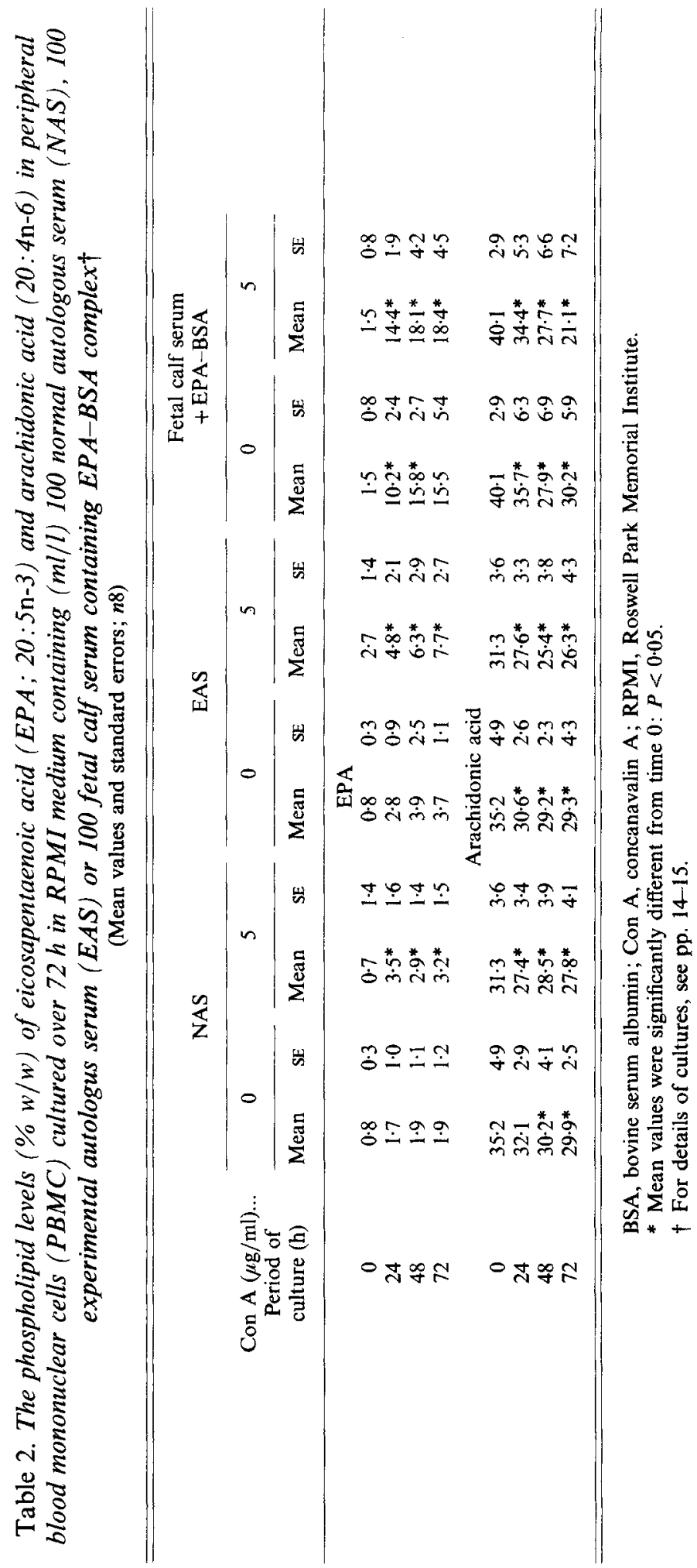


Table 3. Uptake of $\left[{ }^{3} H\right]$ thymidine by lymphocytes transformed by concavalin $A$ (Con $\left.A\right)$ and cultured in media containing $(\mathrm{ml} / \mathrm{l}) 100$ normal autologous serum, 100 experimental autologous serum or 100 fetal calf serum containing bovine serum albumin $(B S A)$ with or without eicosapentaenoic acid $(E P A) \dagger$

(Values are expressed in counts/min and are means with their standard errors)

\begin{tabular}{|c|c|c|c|c|c|c|c|c|}
\hline \multirow{3}{*}{$\begin{array}{c}\operatorname{Con} \mathrm{A} \\
(\mu \mathrm{g} / \mathrm{ml})\end{array}$} & \multicolumn{4}{|c|}{ Autologous serum } & \multicolumn{4}{|c|}{ Fetal calf serum } \\
\hline & \multicolumn{2}{|c|}{ Normal } & \multicolumn{2}{|c|}{ Experimental } & \multicolumn{2}{|c|}{ BSA } & \multicolumn{2}{|c|}{ EPA-BSA } \\
\hline & Mean & $\mathrm{SE}$ & Mean & $\mathrm{SE}$ & Mean & $\mathrm{SE}$ & Mean & SE \\
\hline 0 & 560 & 53 & 531 & 100 & 757 & 256 & 501 & 75 \\
\hline 1 & 1936 & 430 & 2987 & 567 & $1406^{*}$ & 1105 & $6086^{*}$ & 776 \\
\hline 5 & 16122 & 914 & 19806 & 403 & $24295^{*}$ & 1771 & 16625 & 3261 \\
\hline 10 & 23904 & 1458 & 24445 & 1402 & 28700 & 7657 & 26151 & 5919 \\
\hline 20 & 17064 & 1483 & 20969 & 8561 & 19113 & 4757 & 16209 & 5036 \\
\hline
\end{tabular}

* Mean values were significantly different from those for normal autologous serum: $P<0.05$.

$\dagger$ For details of cultures, see p. 15.

were stimulated with Con A (Table 2). In contrast, experimental autologous serum (containing 6-8\% EPA in lipoprotein phospholipids) led to a significant increase $(P<$ 0.05 ) in EPA only when stimulated with Con A. When compared with the appropriate (with or without Con A) values of NAS, the increases seen with EPA-BSA were significantly greater $(P<0.05)$ at all times, while in the stimulated EAS cells, the increases were significantly different at 48 and $72 \mathrm{~h}(P<0 \cdot 05)$. The levels of arachidonic acid $(20: 4 n-6)$ fell in all cell culture systems from the initial values (Table 2 ). Unstimulated cells cultured in either autologous serum showed persistent significant increases in the phospholipid levels of linoleic acid $(18: 2 n-6)$ beginning at 24 h, i.e. from $8 \cdot 1$ to $12.2 \%$ (values not given). The level of 22:6n-3 did not show any consistent pattern of change except in stimulated cells in the EPA-BSA culture at $72 \mathrm{~h}(6.5 v 1.8 \%$ at time 0$)$. At $1-20 \mu \mathrm{g}$ Con A, there were little differences in the uptake of $\left[{ }^{3} \mathrm{H}\right]$ thymidine by cells cultured in the various media. Cultures containing BSA were significantly increased $(P<0.05)$ at $1 \mu \mathrm{g}$ Con A and the culture containing BSA alone was significantly increased $(P<0 \cdot 05)$ over all other cultures at $5 \mu \mathrm{g}$ Con A (Table 3).

\section{DISCUSSION}

The extensive transfer of albumin-bound exogenous fatty acids into cultured PBMC observed in the present study is in keeping with findings reported for other cell culture systems: platelets (Morita et al. 1983; Lagarde et al. 1985), erythrocytes (Mulder \& Van Deenen, 1965), leucocytes (Cunnane et al. 1984), smooth muscle cells (Morisaki et al. 1985), tumour cells (Spector et al. 1981), adipocytes (Abumrad et al. 1984), hepatocytes (Chambaz et al. 1986) and endothelial cells (Spector et al. 1983). Although the mechanism of uptake of free fatty acids is unclear (Scow \& Blanchette-Mackie, 1985) it appears to be rapid, possibly involving neutral lipids as an intermediate stage (Cunnane et al. 1984) and all phospholipid classes (von Schacky \& Weber, 1985). In contrast, the uptake of EPA by blood cells in vivo is slow (von Schacky et al. 1985) and the EPA is not equally incorporated into all phospholipid classes. The findings of von Schacky et al. (1985) suggest that the uptake in vivo of EPA parallels the pattern of fatty acids in the serum phospholipids rather than in the free fatty acids in serum. 
In the present study EPA comprised $14.3 \% \mathrm{w} / \mathrm{w}$ of the free fatty acid fraction of the EAS and $8.6 \% \mathrm{w} / \mathrm{w}$ of the total lipids of this serum. In spite of this, resting cells cultured in the medium containing this serum did not show a significant uptake of EPA from either the free fatty acid pool or the lipoprotein-phospholipid pool. Clearly, the use of exogenous albumin-bound EPA in studies in vitro does not fairly reflect that which occurs in vivo or ex vivo with autologous serum.

In contrast, the uptake of EPA from EPA-rich autologous serum by cells cuitured in the presence of Con A reflects the stimulus to membrane synthesis when this mitogen is present. Loomis et al. (1983) also found that cultured rat splenocytes reflected the composition of the culture serum used, although these authors did not have a control culture, without added mitogen. During blastogenesis there is a marked increase in lymphocyte expression of low-density lipoprotein (LDL) receptors (Cuthbert et al. 1986) for membrane cholesterol leading to enhanced LDL uptake which in the present investigation is rich in EPA. Extensive uptake of serum lipoproteins will also occur in cells which are inherently mitotic such as fibroblasts, smooth muscle cells or endothelial cells, or in cells which are rendered mitotic through cell transformation, such as in tumour cells (Spector et al. 1981). Since peripheral blood cells are not mitotic, uptake of serum lipoproteins would require another mechanism.

Studies in vitro with ${ }^{32} \mathrm{P}$-labelled phospholipids have shown that phospholipid uptake does occur between erythrocytes and serum phospholipids (Reed et al. 1968). However, the rate is slow ( $12 \mathrm{~h}$ half-life), the extent of the exchangeable pool is small and is confined to phosphatidyl choline (60\% exchangeable) and sphingomyelin (30\% exchangeable). Given average values for the distribution of phospholipids in erythrocytes, about $20-30 \%$ of erythrocyte lipids would be exchangeable by this process. However, the use of ${ }^{32} \mathrm{P}$-labelled phospholipids may overestimate the size of the exchangeable pool since Sakagrami et al. (1965) have shown that the preferred substrate for exchange is lyso-phosphatidyl choline (depeleted of a fatty acid at the $\mathrm{S} n-2$ position). It remains possible that this slow and limited exchange reflects uptake of lipoproteins by a low affinity LDL receptor which is not down-regulated in cells (Goldstein et al. 1978). This is seen in the non-significant rise in resting PBMC phospholipid levels of EPA in culture medium with EAS which is rich in endogenous EPA. The small but significant rise in EPA levels of PBMC phospholipids cultured in the NAS in the presence of Con A, reflects the extensive changes which occur in membrane phospholipids with a mitogenic stimulus. In this instance, the fall in arachidonic acid $(20: 4 n-6)$ was paralleled by increases in the levels of palmitic acid $(16: 0)$, linoleic acid (18:2n-6) and EPA (20:5n-3).

In spite of the extensive increase in EPA which occurred in the phospholipid fatty acid compositions of Con A-stimulated PBMC, either with endogenous or exogenous EPA, no significant effect on lymphocyte blastogenesis was observed. The independent stimulatory effect of uncomplexed BSA has been previously recorded (Buttke \& Cuchens, 1984). Studies with rats (Marshall \& Johnston, 1982, 1983) fed on diets containing $\alpha$-linolenic acid $(18: 3 n-3)$ have shown that enrichment of peritoneal macrophages with EPA was associated with reduced macrophage prostaglandin $\mathrm{E}_{2}$ synthesis but was not associated with changes in splenocyte blastogenesis. To date, no information is available on the effect of dietary EPA on lymphocyte responsiveness to various mitogens in man. However, the findings in the present study do not suggest that dietary supplements of EPA would not alter lymphocyte responsiveness.

In summary, the extent of uptake of EPA by Con A-stimulated PBMC is significantly greater when the EPA is exogenously added than when it is an endogenous constituent of autologous serum. Also, resting cells do not incorporate EPA from EPA-enriched autologous serum which contrasts with the rapid uptake by resting cells of exogenous EPA. 
These findings support the view of von Schacky \& Weber (1985) that blood cell fatty acid composition does not immediately reflect that of the plasma milieu but may be defined during cell maturation. Studies of the effects of fish-oil supplements on the long-term uptake of EPA by blood cells are needed with comparisons made of nucleated and nonnucleated cells and phagocytic and non-phagocytic cells.

This work was funded by the Health Research Board, Dublin.

\section{REFERENCES}

Abumrad, N. A., Park, J. H. \& Park, C. R. (1984). Journal of Biological Chemistry 259, 8945-8953.

Buttke, T. M. \& Cuchens, M. A. (1984). Immunology 53, 507-511.

Chambaz, J., Guillouzo, A., Cardot, P., Pepin, D. \& Bereziat, G. (1986). Biochimica et Biophysica Acta 878, $310-319$.

Cunnane, S. C., Keeling, P. W. N., Thompson, R. P. H. \& Crawford, M. A. (1984). British Journal of Nutrition 51, 209-217.

Cuthbert, J. A., East, C. A., Bilheimer, D. W. \& Lipsky, P. E. (1986). New England Journal of Medicine 314, 879-883.

Demacker, P. N., Van Sommeren-Fondag, D. F., Statenhoif, A. F., Stuyt, P. M. \& Van't Laor, A. (1983). Clinical Chemistry 29, 563-565.

Goldstein, J. L., Helegeson, J. A. S. \& Brown, M. S. (1978). Journal of Biological Chemistry 254, 3403-3409.

Gurr, M. I. (1983). Progress in Lipid Research 22, 257-287.

Herold, P. S. \& Kinsella, J. E. (1986). American Journal of Clinical Nutrition 43, 566-598.

Hornstra, G. (1985). Proceedings of the Nutrition Society 44, 371-378.

Lagarde, M., Drouot, B., Guichardant, M. \& Dechavanne, M. (1985). Biochimica et Biophysica Acta 833, $52-58$.

Loomis, R. J., Marshall, L. A. \& Johnston, P. V. (1983). American Journal of Clinical Nutrition 113, 1292-1298. Magrum, L. J. \& Johnston, P. V. (1985). Biochimica et Biophysica Acta 836, 354-360.

Marshall, L. A. \& Johnston, P. V. (1982). Lipids 17, 905-913.

Marshall, L. A. \& Johnston, P. V. (1983). Lipids 18, 737-742.

Morisaki, N., Kanzaki, T., Fujiyama, Y., Osawa, I., Shirai, K., Matsouka, N., Saito, Y., \& Yoshida, S. (I985). Journal of Lipid Research 26, $930-939$.

Morita, I., Saito, Y., Chang, W. C. \& Murota, S. (1983). Lipids 18, $42-49$.

Mulder, E. \& Van Deenen, L. L. M. (1965). Biochimica et Biophysica Acta 106, $106-114$.

Reed, C. F., Murphy, M. \& Roberts, G. (1968). Journal of Clinical Investigation 14, 749-760.

Sakagrami, T., Minari, O. \& Orii, T. (1965). Biochimica et Biophysica Acta 98, 111-118.

Salmon, J. A. \& Terano, T. (1985). Proceedings of the Nutrition Society 44, 385-389.

Sanders, T. A. B. (1985). Proceedings of the Nutrition Society 44, 391-397.

Scow, R. D. \& Blanchette-Mackie, E. J. (1985). Progress in Lipid Research 24, 197-241.

Spector, A. A., Kadyce, T. L., Figard, P. H., Norton, K. C., Hoak, J. D. \& Czervionke, R. L. (1983). Journal of Lipid Research 24, 1595-1604.

Spector, A. A., Mathur, S. N., Kaduce, T. L. \& Hyman, B. T. (1981). Progress in Lipid Research 19, $155-186$. von Schacky, C., Fisher, S. \& Weber, P. C. (1985). Journal of Clinical Investigation 76, 1626-1631.

von Schacky, C. \& Weber, P. C. (1985). Journal of Clinical Investigation 76, 2446-2450. 